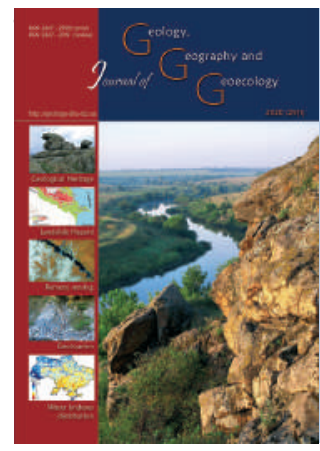

Journal of Geology.

Geography and

Geoecology

ISSN 2617-2909 (print)

ISSN 2617-2119 (online)

Journ.Geol.Geograph.

Geology,

29(2), 422-430.

Journal home page: geology-dnu-dp.ua

doi: $10.15421 / 112038$

Petro S. Voitkiv, Yevhen A. Ivanov

Journ. Geol. Geograph. Geoecology, 29(2), 422-430.

\title{
Specifics of bulk chemical composition of virgin forest cambisols within the Ukrainian Car- pathians
}

Petro S. Voitkiv, Yevhen A. Ivanov

Ivan Franko National University of Lviv,_Lviv,Ukraine,voitkivpetro@gmail.com; eugen_ivanov@email.ua

Received: 25.11 .2019

Received in revised form: 11.12.2019

Accepted: 10.05.2020

Abstract. Material composition is one of the most vital components of soil analysis and it which allows to determine the bulk or elemental composition, to get an insight into the total content of chemical elements per the genetic horizons of a soil profile against the soilforming rock, and to identify the direction of soil formation processes, that is, to establish the genesis of soils. The study objective supposed both the identification of bulk chemical composition (BCC) specifics peculiar to cambisols (acc. the WRB) located beneath different virgin forest ecosystems and the change caused by the composition of soil-forming rock, specifics of mountainous terrain and climatic conditions. The study subject is cambisol of virgin (beech and coniferous) ecosystems formed at the eluvium-deluvium flysch with prevailing sandstones, argillites and siltstones. The study scope is bulk chemical composition of beech and coniferous forest cambisols within the Ukrainian Carpathians and its transformation. Comparative-geographical, comparative-profile, analytical and statistical methods have been used accounting for the above objective. The bulk chemical composition has been determined under the method devised by E.V. Arinushkina. Recalculations and ratios have been used to analyse data on the bulk chemical composition of soils. Our article provides the results of the study of bulk chemical composition of cambisols located beneath beech and the coniferous virgin forests. Changes occurred in this, one of the most conservative, soil substance, under the influence of phytocenotic diversity of virgin forest ecosystems and soil species, are analysed, the nature and direction of changes as well as their main regularities are identified. Molecular ratios for the genetic soil horizons are calculated since they testify the removal of elements outside the soil profile boundaries and are the main factor used to assess the direction of cambisols soil-forming process. The article considers the content of constitutional water and the ratio of change in the siliceous soil part. Results obtained allow suggesting intrinsic weathering in the soils under study. Major reasons of changes in the bulk chemical composition of virgin forest cambisols are caused by the character of vegetation, its aggressiveness with respect to the soil mineral content, by climatic features that affect processes of soil formation in mountainous areas depending on the vertical zonality, and by the composition of soil-forming rocks being the substrate for the studied soils. $\mathrm{SiO}_{2}, \mathrm{Al}_{2} \mathrm{O}_{3}, \mathrm{Fe}_{2} \mathrm{O}_{3}$ oxides form the predominant bulk chemical composition of virgin forest cambisols in the Ukrainian Carpathians. Their total content ranges from 65.59 to $87.56 \%$. The mineral base of virgin forest cambisols is $\mathrm{SiO}_{2}$ and its content in virgin forest cambisols amounts up to $63.46-75.03 \%, \mathrm{Al}_{2} \mathrm{O}_{3}$ sesquioxide content is $13.16-17.14 \%, \mathrm{Fe}_{2} \mathrm{O}_{3}$ content is $4.25-6.83 \%$. Molecular ratios in cambisols located beneath the beech virgin forests postulate the removal of sesquioxides out from a soil profile. For instance, the ratios of $\mathrm{SiO}_{2} / \mathrm{Fe}_{2} \mathrm{O}_{3}$ in beech virgin forests cambisols are $42.8-44.61$ and they decrease sharply at the soil profile bottom to 26.35 , i.e. the removal of $\mathrm{Fe}_{2} \mathrm{O}_{3}$ sesquioxide out from a soil profile is observed. The molar ratio of $\mathrm{SiO}_{2} / \mathrm{R}_{2} \mathrm{O}_{3}$ in cambisols located beneath coniferous virgin forests is narrower than in beech virgin forest cambisols and amounts up to $5.64-5.81$, which is due to the lower content of $\mathrm{SiO}_{2}$ oxide and higher number of $\mathrm{Fe}_{2} \mathrm{O}_{3}$ and $\mathrm{Al}_{2} \mathrm{O}_{3}$ sesquioxides. The analysis of leach factor indices shows that leaching of Calcium and Magnesium oxides is observed in these soils. However, leaching in cambisols located beneath the beech virgin forests is less intense than in cambisols located beneath the coniferous virgin forests. Leaching of Sodium and Potassium oxides in cambisols located beneath the beech virgin forests is minor, and in cambisols located beneath the coniferous virgin forests is weakly expressed.

Keywords: bulk chemical composition, cambisols, virgin forests, sesquioxides, leach factor, constitutional water, ratio of change in the siliceous soil part, intra-soil weathering.

\section{Особливості валового хімічного складу буроземів (Cambisols) пралісів Українських Карпат}

Войтків П.С., Іванов С.А.

Львівський національний університет імені Івана Франка, Львiв, voitkivpetro@gmail.com; eugen_ivanov@email.ua 
Анотація. Речовинний склад є однією $з$ найважливіших складових аналізу грунтів, який дозволяє встановити валовий або елементний склад, отримати уявлення про загальний вміст хімічних елементів по генетичних горизонтах грунтового профілю порівняно з грунтотвірною породою, виявити напрямки процесів грунтотворення, тобто, встановити генезис грунтів. Метою дослідження було вивчення особливостей валового хімічного складу (BXC) буроземів (cambisols за WRB) під різними пралісовими екосистемами та їх зміни, спричинені складом грунтотвірних порід, особливостями гірського рельєфу і кліматичних умов. Об'єктом дослідження є буроземи пралісових (букових і смерекових) екосистем, які сформовані на елювії-делювії флішу 3 переважанням пісковиків, аргілітів та алевролітів. Предметом дослідження $є$ валовий хімічний склад буроземів букових та смерекових пралісів Українських Карпат та його трансформація. Використано порівняльно-географічний, порівняльнопрофільний, аналітичний та статистичний методи. Валовий хімічних склад визначено за методом Е. В. Арінушкіної. Для аналізу даних валового хімічного складу грунтів використовують перерахунки і коефіцієнти. Наведено результати дослідження валового хімічного складу буроземів під смерековими і буковими пралісами. Проаналізовано зміни, які відбулися в цій, одній 3 найконсервативніших субстанцій грунтів, під впливом фітоценотичної різноманітності пралісових екосистем та грунтотвірних порід, встановлено характер і напрямок цих змін, а також їхні головні закономірності. Розраховано молекулярні відношення для генетичних горизонтів грунтів, які свідчать про винесення елементів за межі грунтового профілю, що $є$ основним для оцінки напряму буроземного процесу грунтотворення. Проаналізовано вміст конституційної води і коефіцієнт зміни силікатної частини грунту, які дають можливість говорити про протікання процесу внутрішньогрунтового вивітрювання в досліджуваних грунтах. Головні причини змін валового хімічного складу буроземів пралісів спричинені характером рослинного покриву, його агресивності відносно мінеральної частини грунту, кліматичними особливостями, які по-різному впливають відносно висотної поясності, на процеси грунтотворення в гірських місцевостях та самим складом грунтотвірних порід, на яких утворилися досліджувані грунти. Основу валового хімічного складу буроземів пралісів Українських Карпат становлять оксиди $\mathrm{SiO}_{2}, \mathrm{Al}_{2} \mathrm{O}_{3}, \mathrm{Fe}_{2} \mathrm{O}_{3}$. Сумарний їх вміст коливається в межах 65,59-87,56\%. Основу мінеральної частини буроземів пралісів становить $\mathrm{SiO}_{2}$, вміст якого становить 63,46-75,03\%, вміст півтораоксиду $\mathrm{Al}_{2} \mathrm{O}_{3}$ становить 13,16-17,14\%, а $\mathrm{Fe}_{2} \mathrm{O}_{3}-4,25-6,83 \%$. Молекулярні відношення в буроземах під буковими пралісами констатують винесення півтораоксидів 3 грунтового профілю. Зокрема, відношення $\mathrm{SiO}_{2} / \mathrm{Fe}_{2} \mathrm{O}_{3}$ у буроземах букових пралісів становлять 42,89-44,61, з різким зменшенням у нижній частині грунтового профілю до 26,35, тобто простежується винесення півтораоксиду $\mathrm{Fe}_{2} \mathrm{O}_{3}$ з грунтового профілю. У буроземах під смерековими пралісами молярне відношення $\mathrm{SiO}_{2} / \mathrm{R}_{2} \mathrm{O}_{3}$ вужче, ніж у буроземах під буковими пралісами - 5,64-5,81, що пов'язано з меншою кількістю оксиду $\mathrm{SiO}_{2}$ і більшою кількістю півтораоксидів $\mathrm{Fe}_{2} \mathrm{O}_{3}$ та $\mathrm{Al}_{2} \mathrm{O}_{3}$. Аналіз показників фактору вилуговування засвідчує, що в даних грунтах спостерігається вилуговування оксидів кальцію і магнію. Однак в буроземах під буковим пралісом вилуговування відбувається менш інтенсивно, ніж в буроземах під смерековими пралісами. Вилуговування оксидів натрію і калію в буроземі під буковим пралісом незначне, у грунтах під смерековим пралісом - слабовиражене.

Ключові слова: валовий хімічний склад, буроземи, праліси, півтораоксиди, фактор вилуговування, конституційна вода, коефіцієнт зміни силікатної частини трунту, внутрішньотрунтове вивітрювання.

Introduction. In a process of soil formation, the soil undergoes constant changes reflected in changes in its morphological characteristics, physical and physicalchemical properties as well as in changes in its bulk chemical composition. Material composition is one of the most vital components of soil analysis, which allows to determine the bulk or chemical composition, to get an insight of the total content of chemical elements by the genetic horizons of a soil profile against the soil-forming rock, and to identify the direction of soil formation processes, that is, to establish the genesis of soils. In addition, the analysis results allow the establishment of reserves of certain elements found in the genetic horizons of a soil profile (Arinushkina, 1970; Gerasimov, Glazovskaya, 1960).

The study objective was to identify bulk chemical composition specifics peculiar to cambisols located beneath different virgin forest ecosystems as well as its change caused by various climatic features affecting the processes of soil formation in mountainous areas depending on the vertical zonality and by the composition of soil-forming rocks being the substrate for the studied soils. The problem is partially revealed in the works of American scientists (Gleixner et al., 2009; Perry et al., 2012). The study sub- ject is cambisol of virgin (beech and coniferous) ecosystems formed at the eluvium-deluvium flysch with prevailing sandstones, argillites and siltstones. The study scope is bulk chemical composition of beech and coniferous forest cambisols within the Ukrainian Carpathians and its transformation. The results of the study will contribute to the comparison of cambisols of virgin forest (undisturbed) phytocenoses with cambisols of anthropogenically disturbed ones. Changes in the content of chemical elements have been established to improve the composition and forest cultivation properties of disturbed soils.

Material and methods. Data on bulk chemical composition of cambisols located beneath the beech (the Uzhanskyi National Nature Park (NNP)) and coniferous virgin forests (the Carpathian Biosphere Reserve (CBR)) have been considered (Fig. 1). Comparativegeographical, comparative-profile, analytical and statistical methods have been used accounting for the above objective. The problems of identification of virgin forests in the Ukrainian Carpathians have been studied (Volosyanchuk et al., 2018). The actual issue is the mapping of virgin forests (Spracklen, Spracklen, 2019) and analysis of forest cover changes using remote methods (Kuemmerle et al., 2009). 
The bulk chemical composition has been determined under the method devised by E. Arinushkina. Recalculations and ratios have been used to analyse data on the bulk chemical composition of soils. They pose the base for assessing processes capable to trigger changes in chemical composition of soils mineral part in terms of soils genesis. The underlying mode used for re-calculating of data of bulk chemical analysis is recalculation by the dry soil basis. Data are submitted in percentage form, i.e. relatively to content of various elements and their compounds. Upon re-calculating, the obtained data are correlated with the results of the bulk chemical composition of a soilforming rock to determine changes in soils chemical composition occurred during the soil formation process. However, it is possible to do so only if these soils form on a uniform rock. Some limitations are present due to the fact that changes in chemical composition of the certain horizons should be testified by a soil-forming process itself rather than attributed to the rock uniformity (Myakina, Arinushkina, 1979). the upper soil horizons. According to the research by I. Gogolev, a bulk analysis mostly states the event of removing of sesquioxides not only from the upper horizons but also out from the soil profile in general. The constant down-section decrease in $\mathrm{SiO}_{2}: \mathrm{R}_{2} \mathrm{O}_{3}$ molecular ratio right to the parent rock stratum testify the above. Usually, the value of $\mathrm{SiO}_{2}: \mathrm{R}_{2} \mathrm{O}_{3}$ ratio in the upper soil horizons is circa 6.0 with occasional increase up to $10-11$. According to the data by I. Gogolev, this ratio is circa 4.0 in a parent rock. Downwards the soil profile, the value of $\mathrm{SiO}_{2}: \mathrm{R}_{2} \mathrm{O}_{3}$ and $\mathrm{SiO}_{2}: \mathrm{Fe}_{2} \mathrm{O}_{3}$ ratios decreases confirming the removal of Ferrum and Aluminium during cambisols formation process. The grade of sesquioxides removal is uneven. Besides, within the Carpathians it is sometimes possible to locate cambisols, which bulk analysis does not show the removal of $\mathrm{R}_{2} \mathrm{O}_{3}$. In the coniferous forest cambisols the molecular ratio of $\mathrm{SiO}_{2}: \mathrm{R}_{2} \mathrm{O}_{3}=11$ and in general it remains constant throughout the entire profile, i.e. sesquioxides seem to be stable. However, no such common brown mountain-forest soil sections featur-

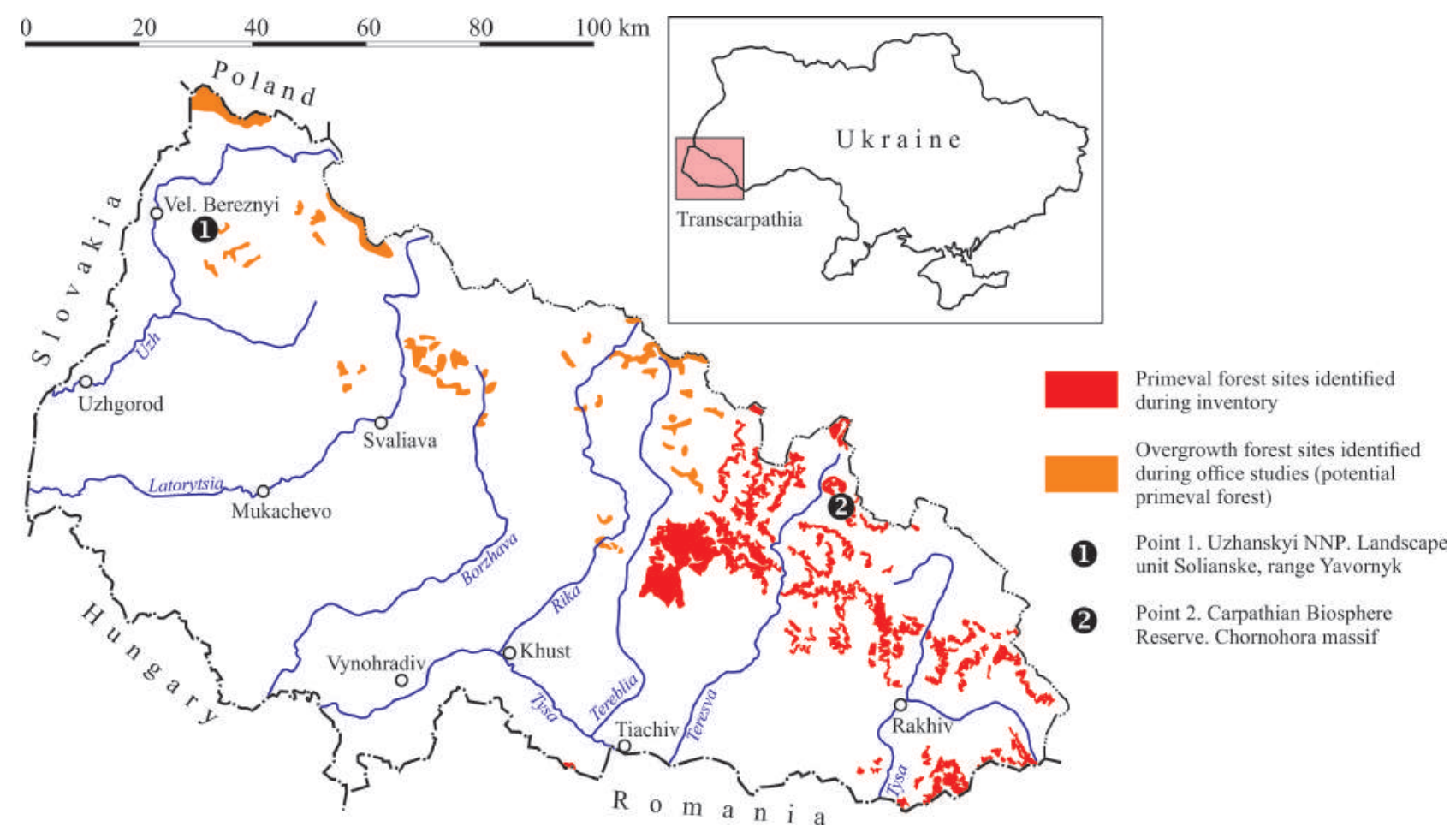

Fig. 1. Data on bulk chemical composition of cambisols of the Transcarpathian virgin forest

Results and their analysis. The results of bulk chemical composition of cambisols found within the study territory do not essentially differ from the results presented in literature (Gogolev, 1965, 1986; Kanivets, 1991; Pasternak, 1967, 1968). Typically, researchers engaged in studying the Carpathian cambisols believe that in the process of cambisols formation sesquioxides, including Ferrum, are accumulated in ing sesquioxides accumulation in the upper horizons have been identified yet (Gogolev, 1986).

The correlation of bulk chemical analysis data to a morphological description of soil profiles allows for the conclusion that the more a soil is gradually developed, less gravelly, and that the thicker a soil profile is, the more expressed the process of sesquioxides removal is demonstrated in it. Cambisols character- 
ised by a high gravel contents throughout the entire profile are young. The bulk analyses justify that during cambisols formation process under the Carpathian conditions sesquioxides do not accumulate, but rather remove out from a soil profile. Moreover, the removal grade in most common cobbly gravelly cambisols is relatively low; it far less than in podzolic soils (Rode, 1937).

The research of bulk chemical composition by P. Pasternak has not testified significant differences in the content of Silicium in a soil profile. In soil sections the varying accumulation of Silicium in the upper horizons is observed as compared to the parent rock, which illustrates the presence of phenomena similar to podzolisation (Pasternak, 1967). The soil beneath a wet coniferous ramen demonstrates an increased Silicium content by $2-4 \%$ as compared to schist. Ferrum sesquioxide composition can be used to identify soils, in which a soil profile including an upper part of the parent rock decreases downwards. In different downstream profile sections the content of $\mathrm{Fe}_{2} \mathrm{O}_{3}$ significantly increases. Certain removal of $\mathrm{Al}_{2} \mathrm{O}_{3}$ is observed; its highest content is identified in the illuvial horizon (Pasternak, 1968). P. Pasternak believes that there is no distinct regularity of $\mathrm{CaO}$ distribution in a soil profile. In general, $\mathrm{CaO}$ is accumulated in the upper horizons while in other horizons it gradually migrates downwards a soil profile. This applies to the soils occurred in smooth slopes conditions. Perhaps, such irrelevant distribution of $\mathrm{CaO}$ is explained by a varied composition of soil-forming rocks. In several sections the content of $\mathrm{MgO}$ decreases in horizon $\mathrm{A}_{2}(\mathrm{Hp})$ and increases in the illuvial horizon, which is typical for podzolic soils. As P. Pasternak affirms, the content of $\mathrm{K}_{2} \mathrm{O}$ in soil profiles varies insignificantly.

So, if we consider a bulk composition, the promoted distribution of Silicium and sesquioxides by the type representative of podzolisation process is observed only in some sections. These sections show a clear evidence of $\mathrm{SiO}_{2}$ accumulation and decrease in Ferrum and Aluminium contents in the illuvial horizon (Pasternak, 1968). Upon correlating chemical composition of soils located beneath different forest types P. Pasternak states that there are no traces of redistribution of oxides typical for podzolisation processes in soils of pure and beech forests. These soils are characterised by $\mathrm{Fe}_{2} \mathrm{O}_{3}$ expressed accumulation in horizons A1 and A2 as compared to horizon B (Pasternak, 1968).

The results of bulk chemical composition analysis conducted for all cambisols located beneath the beech forests testify that soil horizons, as compared to soil-forming rock, are enriched with Silicium. In a humus horizon, the content of Silicium amounts up to $105-110 \%$ from its content in the parent rock (Pasternak, 1968). P. Pasternak explains a possible increase of $\mathrm{SiO}_{2}$ in a humus horizon by its accumulation due to plant litter decomposition. Several authors point to the possibility of Silicium biological accumulation in the upper horizons. B. Polynov conducted a study to define biological accumulation of Silicium in soils covered with beeches, hornbeams, chinquapin trees in the Ajaria region. He showed that plants absorb alumina somewhat more intensively than it returns to the soil thus explaining the fact of Silicium relative accumulation in soil horizons containing plant roots (Polynov, 1944). Data on bulk chemical analysis received by V. Kanivets justify the uniformity of mountain-meadow and mountain-forest cambisols. Despite the fact that these soils are formed on different rocks, their chemical composition is almost the same. Bulk analyses of cambisols conducted for all climatic zones including mountain-forest ones illustrate that humus-accumulative horizon poor on Calcium and Magnesium are simultaneously the most eluviated in respect of $\mathrm{R}_{2} \mathrm{O}_{3}$ (Ferrum above all) as well as Calcium, Sodium and other alkaline earth elements (Kanivets, 1991).

The results of bulk chemical composition analysis completed for cambisols located beneath the beech and the coniferous virgin forests are shown in a form of percentage from the dry soil basis and roasted soil basis, presented in the Tables 1 and 2 .

The bulk chemical composition of the beech virgin forests soils in the Ukrainian Carpathians shown in a form of percentage from the dry soil basis is as follows: oxides of Silicium $\left(\mathrm{SiO}_{2}\right)$, Aluminum $\left(\mathrm{Al}_{2} \mathrm{O}_{3}\right)$, Ferrum $\left(\mathrm{Fe}_{2} \mathrm{O}_{3}\right.$ ) (Table 1). Their content ranges from 77.23 to $87.56 \%$ in cambisols of the beech virgin forests within the Uzhanskyi NNP. In the coniferous virgin forests cambisols within the Chornohora massif their content ranges from 65.59 to $84.98 \%$. Silicium oxide prevails in all studied cambisols. In the beech virgin forests cambisols its content is $62.05-72.30 \%$ while in the coniferous virgin forests cambisols it amounts up to $49.76-63.69 \%$, which is associated with the increased content of "aggressive" fractions of fulvic acids in the cambisols under coniferous virgin forests as opposed to beech virgin forests.

However, BCC data shown in a form of percentage from the dry soil basis do not completely reflect changes in chemical composition of soils occurred subsequently to the formation of the last one. In order to make more detailed reflection of changes in both chemical composition and profile differentiation of elements constituting mineral part of studied soils, 


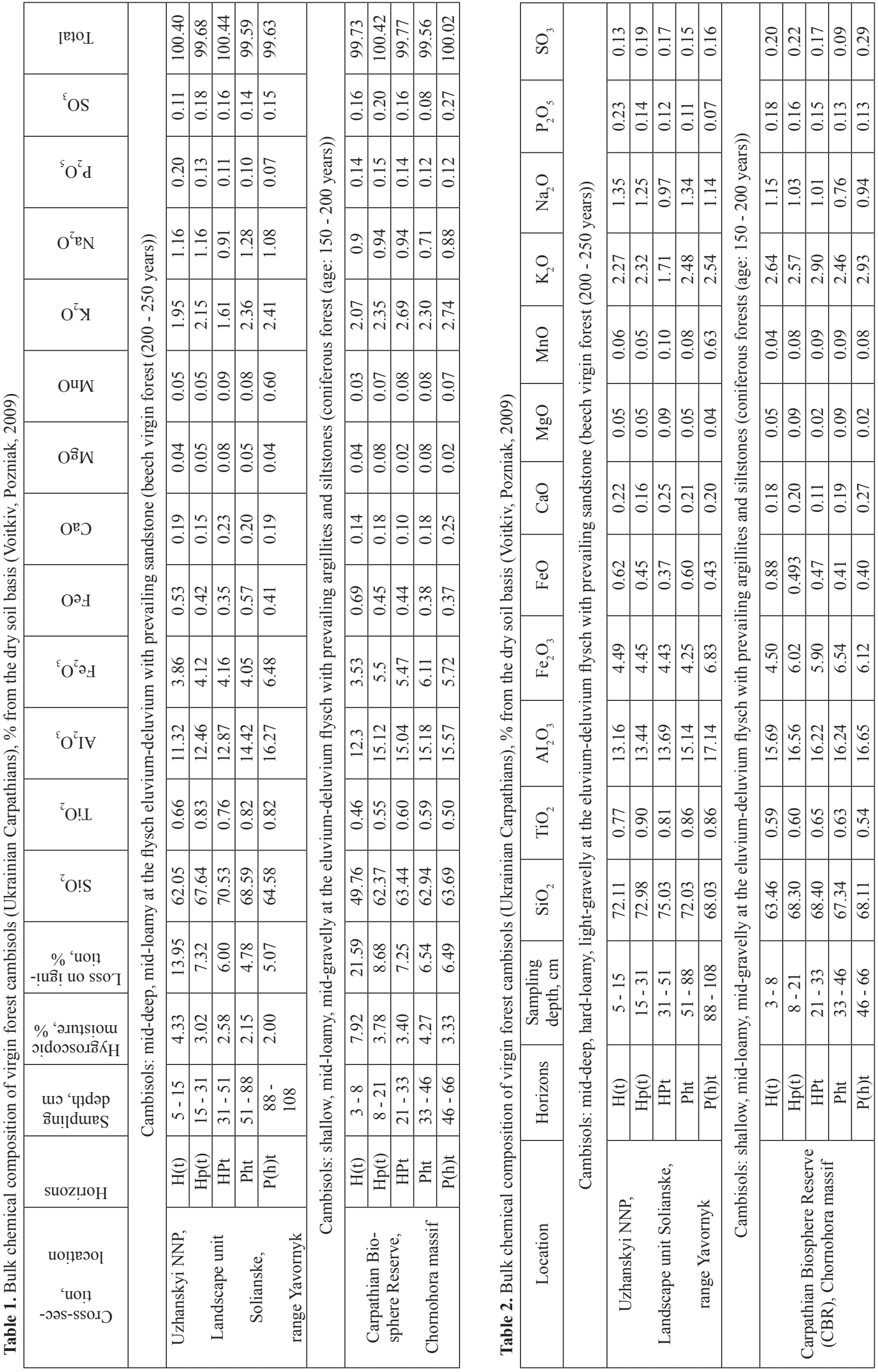


the $\mathrm{BCC}$ results have been re-calculated basing on roasted soil (Table 2).

$\mathrm{SiO}_{2}$ is considered to be the base of mineral part of virgin forest cambisols. For instance, in the beech virgin forests cambisols within the Uzhanskyi NNP at the depths of $51-88 \mathrm{~cm}$ the content of $\mathrm{SiO}_{2}$ ranges from 72.03 to $75.03 \%$. Downwards a profile the relative content of Silicium decreases up to $68.03 \%$. The decrease of $\mathrm{SiO}_{2}$ relative content towards a soilforming rock is caused by the concurrent increase in the relative content of sesquioxides, Aluminium sesquioxide $\left(\mathrm{Al}_{2} \mathrm{O}_{3}\right)$ in particular.

As data in Table 2 suggest, the bulk content of $\mathrm{Al}_{2} \mathrm{O}_{3}$ in the upper horizons is $13.16-13.69 \%$ and reaches its maximum at $31-51 \mathrm{~cm}$ depth, where it ranges from 15.14 to $17.14 \%$. The content of $\mathrm{Fe}_{2} \mathrm{O}_{3}$ sesquioxide in this soil is somewhat low. It ranges from 4.25 to $6.83 \%$ and increases towards a soilforming rock. The distribution of sesquioxides in the coniferous virgin forest cambisols is marginally different. In the upper humus horizon the content of $\mathrm{SiO}_{2}$ amounts up to $63.46 \%$, it slightly increases up to $67.34-68.40 \%$ with depth. The content of $\mathrm{Al}_{2} \mathrm{O}_{3}$ sesquioxide is $15.69-16.65 \%$, the content of $\mathrm{Fe}_{2} \mathrm{O}_{3}$ is $4.50-6.54 \%$. The volume of $\mathrm{FeO}$ in these soils is almost the same. The results of the data see, its highest content, i.e. $0.40-0.88 \%$, is detected in cambisols located beneath the coniferous virgin forests; in beech virgin forest cambisols it is lower and ranges from 0.43 to $0.46 \%$.

The content of Calcium and Magnesium in most studied soils can be characterized as low with some exceptions. In cambisols of beech and coniferous virgin forests the content of $\mathrm{MgO}$ is $0.02-0.09 \%$, which is rather low. The content of Calcium contained in beech virgin forest cambisols, namely in the upper profile part, is $0.22 \%$ (low) and it increases up to $0.25 \%$ with depth. In coniferous virgin forest cambisols the content of Calcium oxide in the upper humus horizons ranges from 0.18 to $0.20 \%$ whilst in the middle profile part it decreases up to $0.11 \%$. At the depth of $33-46 \mathrm{~cm}$ a moderate increase in $\mathrm{CaO}$ content up to $0.19-0.27 \%$ is observed.

The content of $\mathrm{MnO}$ is very low. In cambisols beneath the beech and coniferous virgin forests it ranges from 0.04 to 0.10 (except horizon $\mathrm{P}(\mathrm{h}) \mathrm{t}-0.63 \%$ ). The content of $\mathrm{TiO}_{2}$ in these soils is almost the same; values vary from 0.52 to $0.90 \%$. The content of $\mathrm{K}_{2} \mathrm{O}$ in beech virgin forests cambisols ranges from 1.71 to $2.54 \%$. In the upper horizons of beech virgin forests cambisols values are $2.27-2.32 \%$. At the depth of 31 $51 \mathrm{~cm}$ they decrease up to $1.71 \%$ with the subsequent increase up to $2.54 \%$ with depth. The bulk content of
Sodium oxide $\left(\mathrm{Na}_{2} \mathrm{O}\right)$ in beech virgin forests cambisols is $0.97-1.35 \%$ with minimal values in the middle soil profile part. In coniferous virgin forest cambisols the bulk content of $\mathrm{K}_{2} \mathrm{O}$ is $2.46-2.93 \%$, the content of $\mathrm{Na}_{2} \mathrm{O}$ is $0.76-1.15 \%$. The profile distribution of $\mathrm{K}_{2} \mathrm{O}$ is uneven. In the upper horizons the bulk content is $2.57-2.64 \%$; at the depth of $21-33 \mathrm{~cm}$ it increases up to $2.90 \%$. Downwards a profile the content of Potassium oxide decreases and sharply increases up to $2.93 \%$. The distribution of $\mathrm{Na}_{2} \mathrm{O}$ is characterised by a gradual decrease of the bulk content with depth. The content of $\mathrm{P}_{2} \mathrm{O}_{5}$ in beech virgin forest cambisols is $0.07-0.23 \%$. In coniferous virgin forest cambisols the content of $\mathrm{P}_{2} \mathrm{O}_{5}$ is rather low and ranges from 0.13 to $0.27 \%$. In these profiles the distribution is characterised by a gradual decrease in the content towards a soil-forming rock. The bulk content of $\mathrm{SO}_{3}$ in studied soils is uneven and in beech virgin forest cambisols it ranges from 0.13 to 0.32 while in coniferous virgin forest cambisols it varies from 0.09 to $0.29 \%$. The profile distribution of Sulphur oxide is uneven (Table 2). In beech virgin forest cambisols within the Uzhanskyi NNP the content of $\mathrm{SO}_{3}$ decreases gradually but in coniferous virgin forest cambisols it reaches 0.20 $-0.22 \%$ in the upper humus horizons with stepwise decrease with depth. Starting from the depth of 46 $66 \mathrm{~cm}$ an increase in $\mathrm{SO}_{3}$ content up to $0.29 \%$ is observed (Voitkiv, Pozniak, 2009).

Molecular ratios calculated for genetic soil horizons suggest the removal and accumulation of elements, which is essential to assess the direction of soil-forming processes (Boul, Whole, McCracken, 1977). We have calculated molecular ratios for $\mathrm{SiO}_{2} /$ $\mathrm{R}_{2} \mathrm{O}_{3}, \mathrm{SiO}_{2} / \mathrm{Al}_{2} \mathrm{O}_{3} \mathrm{i} \quad \mathrm{SiO}_{2} / \mathrm{Fe}_{2} \mathrm{O}_{3}$ and they testify unevenness of chemical composition of the soil mineral part (Table 3).

As for cambisols located beneath the beech virgin forests within the Uzhanskyi NNP the bulk analyses state that sesquioxides are removed from a soil profile. In the upper soil horizons the ratio of $\mathrm{SiO}_{2}: \mathrm{R}_{2} \mathrm{O}_{3}$ is $7.59-7.71$, in the lower part it decreases to $5.37-6.81$. The ratio of $\mathrm{SiO}_{2} / \mathrm{Fe}_{2} \mathrm{O}_{3}$ in beech virgin forest cambisols is almost equal, i.e. 42.89 - 44.61, and it sharply increases in the lower horizon $\mathrm{P}(\mathrm{h})$ $t$ up to 26.35, which means that Ferrum sesquioxide is removed from a soil profile. The molecular ratio of $\mathrm{Al}_{2} \mathrm{O}_{3} / \mathrm{Fe}_{2} \mathrm{O}_{3}$ testifies that Aluminium sesquioxide prevails in the soil and it is regularly distributed throughout a profile. In cambisols located beneath the coniferous virgin forests within the Chornohora massif the molar ratio of $\mathrm{SiO}_{2} / \mathrm{R}_{2} \mathrm{O}_{3}$ is narrower than in beech virgin forest cambisols and it ranges from 5.64 to 5.81 . This is mainly due to the lower amount 
Table 3. Profile differentiation indicators of virgin forest cambisols (Ukrainian Carpathians)

\begin{tabular}{|c|c|c|c|c|c|c|c|c|c|c|c|}
\hline 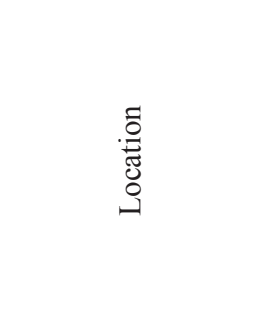 & 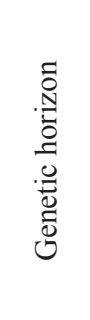 & 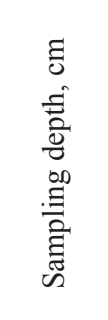 & $\begin{array}{ll}\bigcap^{N} & \bigcap^{m} \\
\mathscr{\simeq}^{N}\end{array}$ & 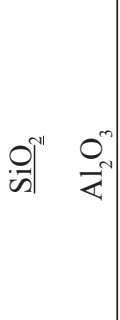 & 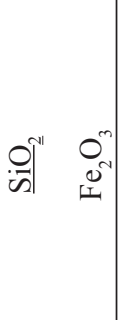 & 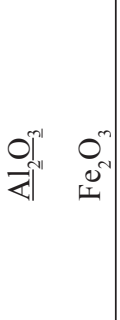 & 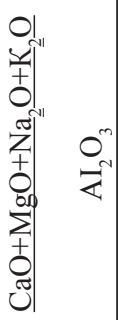 & 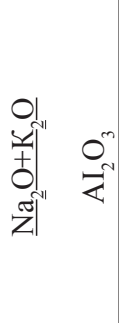 & 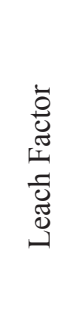 & 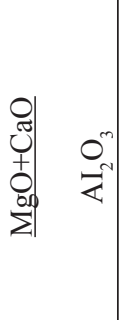 & 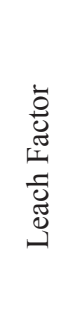 \\
\hline \multicolumn{12}{|c|}{ Cambisols: mid-deep, hard-loamy, light-gravelly at the eluvium-deluvium flysch } \\
\hline \multirow{5}{*}{$\begin{array}{l}\text { Uzhanskyi NNP, } \\
\text { Landscape unit } \\
\text { Solianske, } \\
\text { range Yavornyk }\end{array}$} & $\mathrm{H}(\mathrm{t})$ & $5-15$ & 7.65 & 9.31 & 42.89 & 4.61 & 0.30 & 0.27 & 1.28 & 0.02 & 1.44 \\
\hline & $\mathrm{Hp}(\mathrm{t})$ & $15-31$ & 7.59 & 9.20 & 43.39 & 4.71 & 0.28 & 0.27 & 1.28 & 0.02 & 1.41 \\
\hline & $\mathrm{HPt}$ & $31-51$ & 7.71 & 9.32 & 44.61 & 4.79 & 0.22 & 0.20 & 0.95 & 0.02 & 1.71 \\
\hline & $\mathrm{Pht}$ & $51-88$ & 6.81 & 8.05 & 44.41 & 5.52 & 0.27 & 0.25 & 1.19 & 0.02 & 1.23 \\
\hline & $\mathrm{P}(\mathrm{h}) \mathrm{t}$ & $\begin{array}{l}88- \\
108\end{array}$ & 5.37 & 6.74 & 26.35 & 3.91 & 0.23 & 0.21 & 1.00 & 0.01 & 1.00 \\
\hline \multicolumn{12}{|c|}{$\begin{array}{l}\text { Cambisols: shallow, mid-loamy, mid-gravelly at the eluvium-deluvium flysch } \\
\text { with prevailing argillites and siltstones (coniferous forest (age: } 150 \text { - } 200 \text { years)) }\end{array}$} \\
\hline \multirow{5}{*}{$\begin{array}{l}\text { Carpathian Bio- } \\
\text { sphere Reserve, } \\
\text { Chornohora massif }\end{array}$} & $\mathrm{H}(\mathrm{t})$ & $3-8$ & 5.81 & 6.86 & 37.75 & 5.50 & 0.26 & 0.24 & 1.04 & 0.01 & 0.84 \\
\hline & $\mathrm{Hp}(\mathrm{t})$ & $8-21$ & 5.69 & 7.02 & 29.92 & 4.26 & 0.23 & 0.22 & 0.95 & 0.02 & 0.99 \\
\hline & $\mathrm{HPt}$ & $21-33$ & 5.81 & 7.16 & 30.78 & 4.30 & 0.25 & 0.24 & 1.04 & 0.01 & 0.46 \\
\hline & Pht & $33-46$ & 5.61 & 7.05 & 27.34 & 3.88 & 0.22 & 0.20 & 0.87 & 0.02 & 0.99 \\
\hline & $\mathrm{P}(\mathrm{h}) \mathrm{t}$ & $46-66$ & 5.64 & 6.96 & 29.84 & 4.29 & 0.25 & 0.23 & 1.00 & 0.02 & 1.00 \\
\hline
\end{tabular}

of Silicium oxide and greater amount of Ferrum and Aluminum sesquioxides (Table 3).

Except for the molar sesquioxides ratio, we have calculated molar ratios for the alkaline earth metals in soils: $\mathrm{Na}_{2} \mathrm{O}+\mathrm{K}_{2} \mathrm{O} / \mathrm{Al}_{2} \mathrm{O}_{3}, \mathrm{CaO}+\mathrm{MgO} / \mathrm{Al}_{2} \mathrm{O}_{3}$. Their values served the base to calculate a "leach factor" proposed by H. Jenny (1931). The received indices testify on Calcium and Magnesium leach in relation to $\mathrm{Al}_{2} \mathrm{O}_{3}$ found in beech virgin forest cambisols within the Uzhanskyi NNP (Voitkiv, Pozniak, 2009). Leach factor values indicate an insignificant increase in the middle profile part, i.e. leaching occurs starting from the upper horizons. Leach factor values of Calcium and Magnesium in coniferous virgin forest cambisols within the Chornohora massif indicate the fact of leaching from the middle soil part, which is caused by intensive processes of intra-soil weathering. Leach factor values for $\mathrm{Na}^{+}$and $\mathrm{K}^{+}$in relation to $\mathrm{Al}_{2} \mathrm{O}_{3}$ found in beech virgin forest cambisols testify insignificant leaching, in coniferous virgin forest cambisols leaching is expressed weakly (Table 3 ).

An analysis of the scientific literature on the bulk chemical composition of cambisols indicates that in most cases authors do not provide data on the content of constitutional water in soils (Andrushchenko, 1970; Pasternak, 1967). According to O. Rode (1984), it is obligatory to determine chemically bound water parameters in the course of a bulk chemical analysis of soils. The content of constitutional water has been calculated by the difference between the amount of loss as a result of ignition and humus percentage composition. The received constitutional water content has been converted into a molecular amount (Table 4). Table 4 shows the change indicator in respect of a soil siliceous part, obtained by dividing the molecular amount of constitutional water in one or another soil horizon by its content in the rock. As it is seen, the content of constitutional water in the most upper humus horizon of studied cambisols located beneath the beech and coniferous virgin forests are characterised by a high content, in particular its values range from 6.82 to $8.50 \%$. The change ratio of siliceous part is $1.73-2.01 \%$ (Voitkiv, Pozniak, 2009).

It worth to note that the content of constitutional water downstream a cambisols profile in the coniferous virgin forests is somewhat higher and thus the change ratio for a soil siliceous part is greater than 1, which testify the escalation of intra-soil weathering processes throughout the whole profile. In beech virgin forest cambisols the content of constitutional water reaches its height in humus horizon $\mathrm{H}(\mathrm{t})$. The change ratio value for a soil siliceous part is 1.73 , 
Table 4. Content of constitutional water in cambisols of virgin forests (Ukrainian Carpathians) (Voitkiv, Pozniak, 2009)

\begin{tabular}{|c|c|c|c|c|c|c|c|c|}
\hline $\begin{array}{l}\text { Cross-section, } \\
\text { location }\end{array}$ & 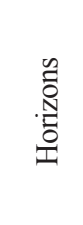 & 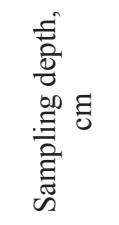 & 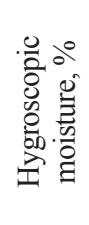 & 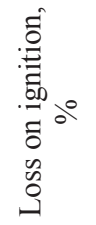 & 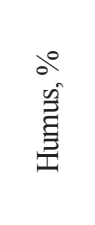 & 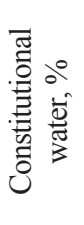 & 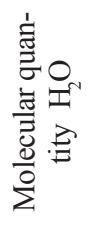 & 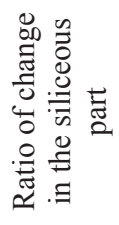 \\
\hline \multicolumn{9}{|c|}{$\begin{array}{l}\text { Cambisols: mid-deep mid-loamy at the eluvium-deluvium flysch with prevailing sandstone } \\
\text { (beech virgin forest (age: } 200-250 \text { years)) }\end{array}$} \\
\hline \multirow{5}{*}{$\begin{array}{l}\text { Uzhanskyi NNP, Land- } \\
\text { scape unit Solianske, } \\
\text { range Yavornyk }\end{array}$} & $\mathrm{H}(\mathrm{t})$ & $5-15$ & 4.33 & 13.95 & 7.13 & 6.82 & 379 & 1.73 \\
\hline & $\mathrm{Hp}(\mathrm{t})$ & $15-31$ & 3.02 & 7.32 & 4.00 & 3.32 & 184 & 0.84 \\
\hline & $\mathrm{HPt}$ & $31-51$ & 2.58 & 6.00 & 2.61 & 3.39 & 188 & 0.86 \\
\hline & $\mathrm{Pht}$ & $51-88$ & 2.15 & 4.78 & 1.35 & 3.43 & 191 & 0.87 \\
\hline & $\mathrm{P}(\mathrm{h}) \mathrm{t}$ & $88-108$ & 2.00 & 5.07 & 1.12 & 3.95 & 219 & 1.00 \\
\hline \multicolumn{9}{|c|}{$\begin{array}{l}\text { Cambisols: shallow, mid-loamy, mid-gravelly at the eluvium-deluvium flysch } \\
\text { with prevailing argillites and siltstones (coniferous forests (age: } 150 \text { - } 200 \text { years)) }\end{array}$} \\
\hline \multirow{2}{*}{$\begin{array}{c}\text { Carpathian Biosphere } \\
\text { Reserve, }\end{array}$} & $\mathrm{H}(\mathrm{t})$ & $3-8$ & 7.92 & 21.59 & 13.09 & 8.50 & 472 & 2.01 \\
\hline & $\mathrm{H}(\mathrm{t})$ & $8-21$ & 3.78 & 8.68 & 3.90 & 4.78 & 266 & 1.13 \\
\hline \multirow[t]{3}{*}{ Chornohora massif } & $\mathrm{Hpt}$ & $21-33$ & 3.40 & 7.25 & 2.89 & 4.36 & 242 & 1.03 \\
\hline & $\mathrm{Pht}$ & $33-45$ & 4.27 & 6.54 & 2.38 & 4.28 & 238 & 1.01 \\
\hline & $\mathrm{P}(\mathrm{h}) \mathrm{t}$ & $45-66$ & 3.33 & 6.49 & 2.26 & 4.23 & 235 & 1.00 \\
\hline
\end{tabular}

which testify the escalation of intra-soil weathering processes; downstream a profile the content of constitutional water is almost constant, the coefficient is less than one.

Conclusions. The analysis of study results of bulk chemical composition of beech and coniferous virgin forests cambisols located within the Ukrainian Carpathians allows to make conclusions as follows:

1. Bulk chemical composition reflects the conditions of soil formation within the study territory and manifestation of both past and present soilforming processes.

2. Silicium oxide $\left(\mathrm{SiO}_{2}\right)$, Aluminium oxide $\left(\mathrm{Al}_{2} \mathrm{O}_{3}\right)$ and Ferrum oxide $\left(\mathrm{Fe}_{2} \mathrm{O}_{3}\right)$ are the base for bulk chemical composition of virgin forest cambisols within the Ukrainian Carpathians. Their total content ranges from 77.23 to $87.56 \%$ in beech virgin forest cambisols and from 65.59 to $84.98 \%$ in coniferous virgin forest cambisols. The base for the mineral part of virgin forest cambisols is $\mathrm{SiO}_{2}$, which content in beech virgin forest cambisols is $68.03-75.03 \%$; the bulk content of $\mathrm{Al}_{2} \mathrm{O}_{3}$ sesquioxide is $13.16-17.14 \%$ and for Ferrum $\left(\mathrm{Fe}_{2} \mathrm{O}_{3}\right)-4.25-6.83 \%$. In coniferous virgin forest cambisols the content of $\mathrm{SiO}_{2}$ is 63.46 $68.40 \%$, for $\mathrm{Al}_{2} \mathrm{O}_{3}$ sesquioxide is $15.69-16.65 \%$ and for $\mathrm{Fe}_{2} \mathrm{O}_{3}$ is $4.50-6.54 \%$.

3 . The calculated molecular ratios in cambisols located beneath the beech virgin forests confirm the removal of sesquioxide out from a soil profile. The ratio of $\mathrm{SiO}_{2} / \mathrm{Fe}_{2} \mathrm{O}_{3}$ in the beech virgin forests is 42.89 - 44.61 and it sharply increases in the lower part of a soil profile up to 26.35 testifying the removal of Ferrum sesquioxide out from a soil profile. The molecular ratio of $\mathrm{Al}_{2} \mathrm{O}_{3} / \mathrm{Fe}_{2} \mathrm{O}_{3}$ indicates the prevalence of Aluminium sesquioxide over Ferrum in soil and its even distribution throughout a profile.

4. Leach factor indicators testify that Calcium and Magnesium oxides leaching is observed in study soils. However, in beech virgin forest cambisols leaching is less intensive than in coniferous virgin forests cambisols. Leaching of Sodium and Potassium oxides in cambisols located beneath the beech virgin forests is insignificant, and in cambisols located beneath the coniferous virgin forests is expressed weakly.

5. The escalation of intra-soil weathering processes is observed in the upper part of a humus horizon of beech virgin forest cambisols and throughout the whole profile of coniferous virgin forest cambisols, which is testified by an increased content of constitutional water and change ratio of siliceous soil part. In particular, the content of constitutional water in the most upper humus horizon of studied cambisols located beneath the beech and coniferous virgin forests is characterized by a high content, i.e. 6.82 $-8.50 \%$. The change ratio of siliceous part is 1.73 $2.01 \%$. Downstream a profile the content of constitutional water in cambisols beneath the beech virgin forests is somewhat higher and thus the change ratio for a soil siliceous part is greater than 1 . In beech virgin forests cambisols the content of constitutional 
water reaches its height in a humus horizon where the change ratio of a siliceous part is 1.73 . The purpose of the study was achieved. The results of the study will contribute to the comparison of cambisols of virgin forest phytocenoses with cambisols of anthropogenically disturbed ones. Changes in the content of chemical elements have been established to improve the composition and forest cultivation properties of disturbed soils.

\section{References}

Andrushchenko, G.O., 1970. Grunty Zakhidnykh oblastei URSR [Soils of the Western regions of the Ukrainian SSR]. Lviv-Dublyany (in Ukrainian).

Arinushkina, E.V., 1970. Rukovodstvo po himicheskomu analizu pochv [Guidelines for Chemical Analysis of Soils]. Moscow University Press, Moscow (in Russian).

Boul, S.W., Whole, F.D., \& McCracken, R.J., 1977. Genezis i klassifikacija pochv [Soil Genesis and Classification] / translation from English by M.I. Gerasimova. Progress, Moscow (in Russian).

Gerasimov, I.P., \& Glazovskaya, M.A., 1960. Osnovy pochvovedenija i geografija pochv [Fundamentals of Soil Science and Geography of Soils]. Geographiz, Moscow (in Russian).

Gleixner, G., Tefs C., Jordan A., Hammer, M., Wirth, C., Nueske, A., Telz, A., Schmidt, U.E., \& Glatzel S., 2009. Soil Carbon Accumulation in OldGrowth Forests. Old-Growth Forests. Springer, Berlin-Heidelberg, 231-266. doi: https://doi. org/10.1007/978-3-540-92706-8

Gogolev, I.N., 1965. Burye gorno-lesnye pochvy Sovetskih Karpat [Brown mountain forest soils of the Soviet Carpathians] Doctoral Thesis in Agricultural Sciences, Lviv (in Russian).

Gogolev, I.N., 1986. Pochvy Ukrainskih Karpat. Priroda Ukrainskoj SSR [Soils of the Ukrainian Carpathians. Nature of the Ukrainian SSR]. Kiev (in Russian).

Jenny, H., 1931. Behavior of potassium and sodium during the process of soil formation. Missouri Agric. Exp. Sta. Res. Bull., 162.

Kanivets, V.I., 1991. Burozemoobrazovanie v lesnyh pochvah Ukrainskih Karpatah [Cambisols formation in Forest Soils of the Ukrainian Carpathians] Soil Science, 4, 19-28 (in Russian).

Kuemmerle, T., Chaskovskyy, O., Knorn, J., Radeloff, V.C., Kruhlov, I., Keeton, W.S., \& Hostert, P., 2009. Forest cover change and illegal logging in the Ukrainian Carpathians in the transition period from 1988 to 2007. Remote Sensing of Environment, 113(6),1194-1207. doi: https://doi. org/10.1016/j.rse.2009.02.006

Myakina, N.B., \& Arinushkina, E.V., 1979. Metodicheskoe posobie dlja chtenija rezul'tatov himicheskih analizov pochv [Study Guide for Reading Results of Soils Chemical Analyses] Moscow University Press, Moscow (in Russian).

Pasternak, P.S., 1967. Lisovi grunty Ukrainskykh Karpat [Forest Soils of the Ukrainian Carpathians] Uzhhorod (in Ukrainian).

Pasternak, P.S., 1967. Vzaimodejstvie mezhdu lesom i pochvoj $\mathrm{v}$ bukovyh nasazhdenijah [Interaction Between Forest and Soil in Beech Stands] Forestry and Agricultural Afforestation, 12, 3-11 (in Russian).

Pasternak, P.S., 1968. Vzaimodejstvie mezhdu lesom i pochvoj v osnovnyh tipah lesa Ukrainskih Karpat [Interaction Between Forest and Soil in Main Types of Forests of the Ukrainian Carpathians] Doctoral dissertation in Agricultural Sciences. Ivano-Frankivsk, P. 2, 390-560 (in Russian).

Perry, D.A., Griffiths, R.P., Moldenke, A.R., Madson, S.L., 2012. Abiotic and Biotic Soil Characteristics in Old Growth Forests and Thinned or Unthinned Mature Stands in Three Regions of Oregon. Diversity, 4, 334-362. doi: https://doi.org/10.3390/ d4030334

Polynov, B.B., 1944. Valovoj pochvennyj analiz i ego tolkovanie [Bulk Soil Analysis and Its Interpretation] Soil Science. 10. $482-490$ (in Russian).

Rode, A.A., 1937. Podzoloobrazovatel'nyj process [Podzol Formation Process] AS of the USSR, Moscow (in Russian).

Rode, A.A., 1984. Sistema metodov issledovanija v pochvovedenii [System of Research Methods in Soil Science] Nauka, Novosibirsk (in Russian).

Spracklen, B.D., \& Spracklen, D.V., 2019. Identifying European Old-Growth Forests using Remote Sensing: A Study in the Ukrainian Carpathians. Forests, 10, 127-145. doi: https://doi.org/10.3390/ f10020127

Voitkiv, P.S., \& Pozniak S.P., 2009. Burozemy pralisiv Ukrainskykh Karpat [Cambisols of Virgin Forests in Ukrainian Carpathians]. Lviv Ivan Franko National University Press, Lviv (in Ukrainian).

Volosyanchuk, R., Prots, B., Shparyk, Y., Cherniavskyi, M., Kagalo, A., \& Savchyn, V., 2018. Old Growth Forests in the Ukrainian Carpathians: Criteria and Indicators, identification methodology, and results up-to date. 5th European Congress of Conservation Biology. doi: 10.17011/conference/ eccb2018/107781 